\title{
RENCANA PENANGANAN LINGKUNGAN PERMUKIMAN KUMUH BERBASIS KAWASAN DI KABUPATEN REMBANG
}

\author{
Enik Kristiana $^{1}$ \\ ${ }^{1}$ Universitas Indraprasta PGRI, Program Studi Arsitektur \\ kristianahamzah@gmail.com
}

\begin{abstract}
:
The purpose of this study is the realization of a development plan-level plan to improve the quality of housing and slum areas. The creation of a plan for handling housing and slum areas in order to improve the quality of life of the people in the environment. The research method used is qualitative descriptive research. Based on the results of the search and preliminary study of the existing conditions of Desa Waru it can be concluded that the village has local potential that has not been maximized both natural resources and human resources. Seeing this potential, the study team tried to purge the direction of the development of Desa Waru in the future in the form of Energy Independent Villages.
\end{abstract}

Key Words: Settlement Planning, Environmental Architecture Slums

\begin{abstract}
Abstrak :
Tujuan penelitian ini adalah terwujudnya suatu rencana setingkat development plan untuk peningkatan kualitas kawasan perumahan dan permukiman kumuh. Terciptanya suatu rencana penanganan kawasan perumahan dan permukiman kumuh agar dapat meningkatkan kualitas kehidupan masyarakat yang berada di lingkungan tersebut. Metode penelitian yang digunakan, penelitian deskriptif kualitatif. Berdasarkan hasil penelusuran dan kajian awal terhadap kondisi eksisting Desa Waru dapat disimpulkan sebagai desa yang memiliki potensi lokal yang belum dimaksimalkan baik itu sumber daya alam maupun sumber daya manusianya. Melihat potensi tersebut tim studi mencoba mengerucutkan arahan pengembangan Desa Waru pada masa yang akan datang dalam bentuk Desa Mandiri Energi.
\end{abstract}

Kata Kunci : Perencanaan Permukiman, Arsitektur Lingkungan, Permukiman Kumuh

\section{PENDAHULUAN}

Pemukiman kumuh merupakan masalah yang dihadapi oleh hampir semua kota- kota besar di Indonesia bahkan kota-kota besar di negara berkembang lainnya. Perkembangan suatu kota tidak terlepas dari pertumbuhan penduduk. Berkaitan dengan hal tersebut terdapat berbagai macam sebab yang mendorong adanya pertumbuhan penduduk secara umum, diantaranya adalah akibat dari tingginya angka perpindahan penduduk dari desa ke kota atau sering disebut sebagai arus urbanisasi. Peningkatan jumlah penduduk atau pendatang tentu akan mendorong peningkatan terhadap jumlah kebutuhan ruang untuk bermukim yakni perumahan dan pemukiman. Sebagian besar wilayah kota-kota besar di Indonesia ditempati oleh pemukiman tidak terencana yang salah satunya dinamakan kampung.

Menurut Kamus Tata Ruang (1997:112) urbanisasi adalah perubahan secara keseluruhan atau transformasi tatanan masyarakat yang semula dominan perdesaan menjadi dominan perkotaan; dalam arti terbatas juga disebut pertambahan penduduk suatu kota sebagai akibat migrasi penduduk dari wilayah perdesaan sekitarnya atau karena perpindahan penduduk dari kota lain. Hal ini dikaitkan dengan kenyataan bahwa di negaranegara maju perpindahan penduduk dari desa ke kota telah dijamin oleh tersedianya lapangan pekerjaan non pertanian di kota-kota, tetapi umumnya di negara sedang berkembang pekerjaan non pertanian di kota tidak terjamin (Sujarto dalam Kuswartojo, 2005).

Desa Waru adalah sebuah desa yang mengalami pertumbuhan yang sangat lambat bila dibandingkan dengan desa-desa yang berada di Kecamatan Rembang dan masih belum tertatanya desa tersebut mengingat keterbatasan dana dan Sumber Daya Manusia yang mengelola Desa tersebut. Desa Waru dapat dikategotikan sebagai kawasan Pesisir, hal ini dikarenakan secara geografis berada di daerah pinggir laut dan $50 \%$ penduduknya adalah Nelayan. Pola pengembangan Desa Waru terjadi secara alamiah seiring dengan bertambahnya jumlah penduduk pada desa tersebut. Desa dipisahkan oleh jalan poros yang membelah desa tersbut dan memiliki 
batas yang sangat unik mengingat batas-batas desa yang tidak menggunakan bentang alam sebagai acauan dalam pembuatan tapal batas.

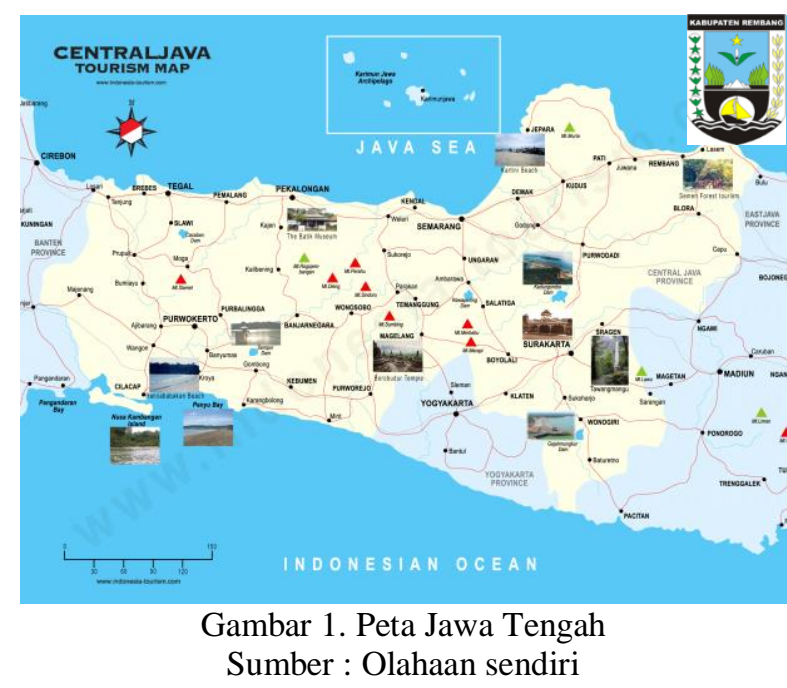

Lokasi studi berada di Desa Waru Kecamatan Rembang, Kabupaten Rambang Jawa Tengah yang berjarak sekitar 5.2 Km dari Ibu Kota Rembang. Ibu Kota Rembang dilalui oleh Jalur Jalan Pantau Utara (pantura) Pulau Jawa. Kabupaten Rembang berbatasan dengan:

Sebelah utara : Laut Jawa

Sebelah Timur : Provinsi Jawa Timur

Sebelah Selatan : Kabupaten Purwodadi

Sebelah Barat : Kabupaten Pati, Kudus dan Jepara

Secara geografis, kabupaten Rembang berada paling timur dari provinsi Jawa Tengah yang berbatasan dengan provinsi Jawa Timur. Hal ini menjadikan Rembang menjadi kota Transit dan dapat dikembangkan menjadi kota yang mampu tumbuh dengan memanfaatkan letak yang sangat strategis.

Desa Waru terletak di wilayah Perkotaan Rembang BWK V Fungsi yang dibebankan adalah sebagai kawasan permukiman dan berdasarkan fungsi tersebut fungsi yang dibebankan adalah untuk peruntukan dengan dominasi: Permukiman berkepadatan rendah, Pendidikan Elemen-elemen penunjang untuk peruntukan dengan dominasi kegiatan terdiri dari: Peribadahan, Kesehatan, Open space / Lapangan , Pertanian, Industri pengolah hasil Pertanian.

Luas permukiman di Desa Waru adalah 67,95 Ha dengan jumlah rumah pada akhir tahun 2007 sebanyak 1.135 rumah, $54 \%$ dari jumlah tersebut merupakan bangunan rumah dengan kondisi tidak layak huni. (regionalinvestment.bkpm.go.id)

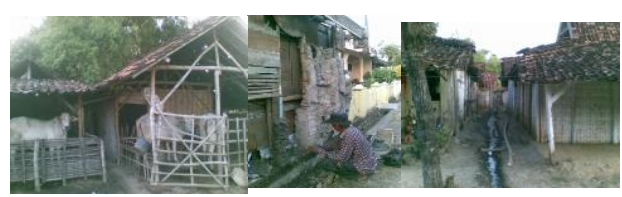

Gambar 2. Keadaan Desa Waru

Desa dengan kondisi lingkungan yang unik (hampir setiap rumah mempunyai hewan ternak sapi) di mana Desa Waru seperti pasar hewan yang di jajakan di setiap sudut rumah.

Lingkungan Permukiman yang menyatu dengan kandang ternak sudah dianggap sebagai hal yang lumrah bagi penghuninya, tingkat pengetahuan yang relatif rendah menyebabkan kesadaran akan kebutuhan lingkungan yang sehat jauh dari pemahaman mereka.
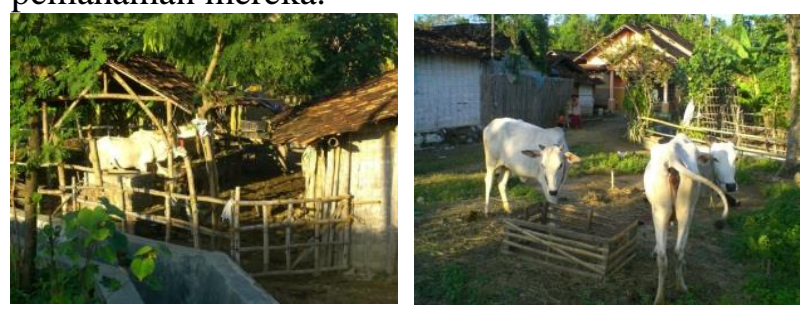

Gambar 3. Kandang Sapi

\section{METODOLOGI}

Metode penelitian yang digunakan dalam penelitian ini adalah penelitian deskriptif kualitatif. Artinya data yang digunakan bukan berupa angka, melainkan data tersebut berasal dari wawancara, catatan lapangan, dokumen pribadi, catatan, memo, dan dokumen resmi lainnya. (Sugiyono, 2003:14)

\section{HASIL DAN PEMBAHASAN \\ Pengolahan Energi Alternatif}

Bila melihat kebutuhan energi yang sangat tinggi pada Desa Waru baik itu untuk keperluan tingkat rumah tangga hingga usaha-usaha pengembangan sektor perekonomian dan kesemua energi-energi tersebut diperoleh dengan membeli sumber energi yang dijual dipasaran. Seperti contoh energi listrik yang berasal dari PLN sebagai pemasok listrik utama pada Desa Waru, dan apabila saluran listrik padam maka masyarakat hanya menerima dengan lapang dada. Sedangkan untuk mencoba mendatangkan sumber energi listrik dengan menggunakan generator dirasa sangat mahal biaya operasionalnya. Begitu juga untuk keperluan memasak bagi kaum ibu-ibu yang mengandalkan minyak tanah dan gas elpiji yang berasal dari Pertamina sebagai pemasok utama dibidang energi tersebut. Kelangkaan minyak tanah dan sedikitnya pasokan gas elpiji membuat 
harga yang tak menentu belum lagi apabila pasokan distribusi terganggu akan membuat kaum ibu-ibu sangat kesulitan untuk memasak. Jikalau ada upaya untuk mencari energi baru untuk memasak biasanya warga menggunakan kayu bakar untuk memasak, akan tetapi pasokan kayu bakar sudah sangat langka dan apabila dilakukan penebangan pohon maka akan merusak lingkungan. Hal seperti ini sangat sering dirasakan oleh masyarakat Desa Waru dan untuk itu diperlukan sebuah upaya untuk mencari sumber energi baru sebagai solusi dari kebutuhan energi tersebut diatas. Diharapkan dengan adanya solusi dalam pengadaan sumber energi alternatif yang menggunakan potensi desa akan menjadikan Desa Waru sebagai Desa Mandiri Energi. Untuk itu pengembangan sumber energi terbaharukan diperlukan sebagai salah satu upaya pemenuhan kebutuhan listrik dan menjadikan Desa Waru sebagai desa yang memiliki produktifitas dan pemberdayaan masyarakat desa yang tinggi pada masa yang akan datang.

Bio Energi merupakan sumber energi yang dihasilkan melalui proses biologis baik itu pada hewan maupun pada tanaman yang dioleh sedemikian rupa untuk diambil gasnya. Berikut ini adalah sumber-sumber bio energi yang diperoleh dari beberapa komoditi yang terdapat pada Desa Waru dan dapat dikembangkan secara konvensional pada tingkat rumah tangga hingga pada tingkat kawasan. Bio energi ini dapat secara langsung digunakan untuk keperluan sehari-hari dalam kebutuhan energi baik itu untuk tingkat rumah tangga hingga tingkat industri rumah tangga.

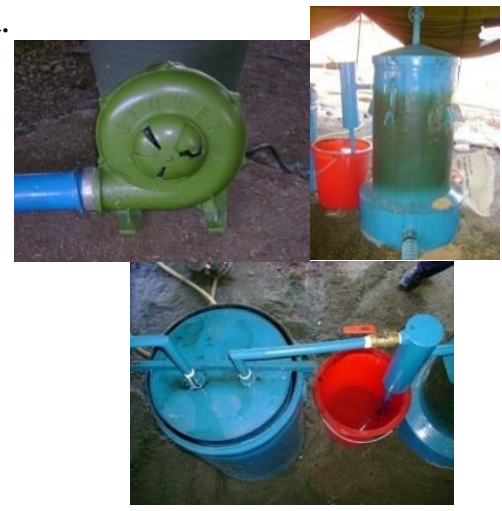

Gambar 4. Bio Energi

Sekam padi merupakan sebuah komoditi yang ada di Desa Waru dan saat ini sekam padi pada beberapa penggilingan padi hanya menjadi sampah yang penggunaannya sangat terbatas. Kabanyakan sekam padi hanya dijual ke kilang pembuatan batu bata dan genteng sebagai bahan baku untuk membakar batu bata dan genteng tersebut. Kebutuhan akan industri tersebut sangat sedikit dan diperlukan sekam yang benar-benar kering mengingat sekam padi yang ada terletak pada ruangan terbuka dan apabila hujan datang maka sekam tersebut menjadi basah dan tidak memiliki nilai untuk dijual yang pada akhirnya menjadi sampah yang menumpuk pada kilang penggilingan padi.

Melihat sekam padi yang terbuang tersebut, tim studi menyarankan agar sekam padi terbut dijadikan bahan baku untuk menjadi sumber energi dalam bentuk biogas melalui pengolahan dengan prinsip pembakaran tidak sempurna. Sekam padi yang dibakar pada media akan diolah dengan cara melakukan pemisahan gas metan dengan gas-gas lain yang terdapat pada pembakaran tersebut. Dengan melakukan konversi dari gas metan ke dalam biogas sudah dapat dikonsumsi dalam bentuk gas yang memiliki kandungan gas yang sama dengan gas elpiji yang benyak ditemukan dipasaran. Dengan media selang yang menghubungkan tabung gas dari biogas ke kompor gas, maka biogas telah dapat dipakai untuk memasak. Begitu juga untuk penggunaan biogas sebagai sumber bahan baku untuk menggerakkan generator sebagai energi listrik. Dengan membakar sekitar $50 \mathrm{~kg}$ sekam padi akan diperoleh biogas untuk memasak selama 3 hari untuk 3-4 keluarga dan menghidupkan generator sebgai sumber energi listrik selama 1,5 jam dengan keluaran 1500 watt dengan tegangan 220 volt. Bila melihat pasokan sekam padi yang terdapat pada Desa Waru akan mampu memenuhi kebutuhan memasak untuk tingkat rumah tangga selama 1 tahun penuh atau kebutuhan listrik selama 3 bulan. Penggunaan energi biogas dari sekam padi ini dapat menjadi sebuah alternatif dalam pemenuhan energi gas dan listrik pada Desa Waru.

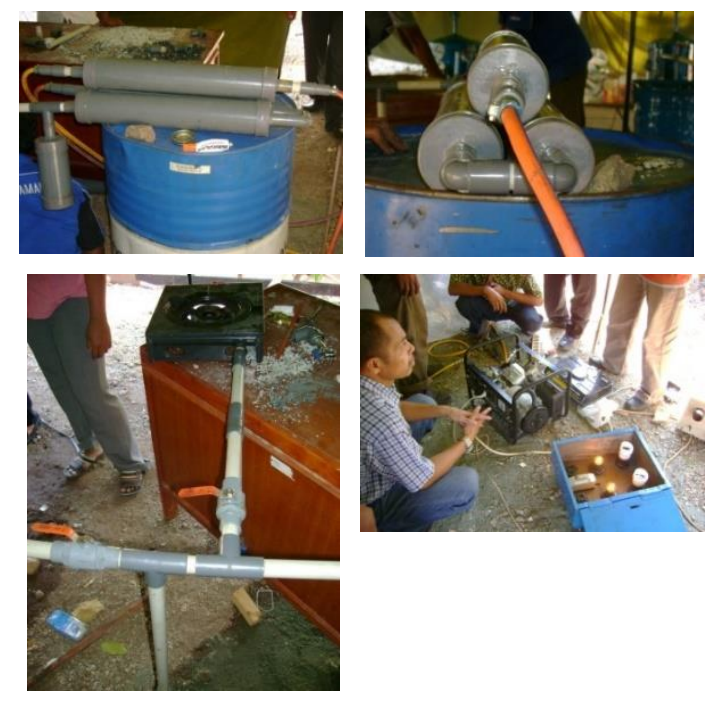

Gambar 5. Sekam Padi 
Limbah padat yang dihasilkan dari kotoran sapi atau yang disebut TA1 dapat dioleh menjadi biogas dengan proses memisahkan gas yang berasal dari kotoran tersebut menjadi biogas dengan cara membekap kotoran sapi tersebut pada sebuah media dan memberikan sebuah selang yang berguna untuk mendistribusikan gas hasil proses alami menjadi biogas ke tabung gas. Biogas yang diperoleh dari kotoran sapi tersebut memiliki kadar yang sama dengan gas yang berasal dari Pertamina dan dapat secara langsung dipergunakan sebagai bahan bakar untuk memasak dan sumber energi listrik. Dengan menggunakan kotoran sapi sebanyak 3-5 ekor dan diperkirakan timbulan limbah TA1 setiap harinya sekitar 20-25 $\mathrm{kg}$ maka diperoleh biogas untuk memasak selama 2 hari dan listrik selama 1 jam dengan kekuatan 1500 watt bertegangan 220 volt. Sedangkan sisa TA1 dari proses biogas tersebut dapat olah kembali menjadi pupuk kompos dan dapat dipakai sebagai pupuk organik pada tanaman pertanian milik warga desa.

Biokeroson atau yang disebut minyak tanah dapat diperoleh dengan mengolah sampah basah yang dihasilkan olaeh masyarakat Desa Waru. Dimana sampah tersebut dilakukan penumpukan hingga diperoleh cairan yang nantinya akan diproses menjadi biokeroson atau yang disebut sebagai minyak tanah. Mengingat di Desa Waru masih banyak anggota masyarakat yang masih menggunakan minyak tanah sebagi sumber energi untuk memasak. Akan tetapi langkanya minyak tanah dan harga yang membumbung tinggi dikarenakan minyak tanah yang ada dipasaran saat ini sudah tidak disubsidi lagi oleh Pemerintah dan dianggap sangat berat.

Biofeul atau biosolar juga dapat diolah sebagai pemenuhan energi khususnya minyak solar untuk kebutuhan anggota masyarakat yang berprofesi sebagai nelayan. Harga solar yang dianggap sangat mahal dapat ditekan dengan cara membuat biosolar pada tingkat rumah tangga dan dapat ditingkatkan produksi biosolar tersebut sesuai dengan kebutuhan. Bahan baku dari biosolar yang terdapat pada Desa Waru adalah mengubah penghijauan milik masyarakat dari pohon yang memiliki buah untuk dimakan diubah dengan menanam pohon jarak pagar. Diharapkan dengan melakukan penghijauan pada pekarangan rumah akan memberikan kesejukan dan buah dari tanaman jarak pagar tersebut dapat dijadikan bahan baku untuk membuat biosolar. Begitu juga dengan sisa minyak goreng yang disebut sebagai minyak jelantah yang biasanya dibuang karena sudah tidak layak untuk digunakan kembali dapat diolah menjadi biosolar. Dengan mengolah minyak jelantah tersebut menjadi biosolar akan mengurangi dampak lingkungan akibat minyak sisa terbuang akan sangat sulit diurai oleh tanah dan biasanya menimbulkan bau yang tak sedap.

\section{Gagasan Fisik Kawasan Prioritas}

Berdasarkan partisipatif awal oleh warga masyarakat dan identifikasi awal serta kompilasi dengan program dari BKM PNPM Mandiri, maka dapat diidentifikasi rencana program awal berisi tentang rencana peningkatan kualitas lingkungan sebagai berikut :

Tabel 1. Rencana Peningkatan Kualitas
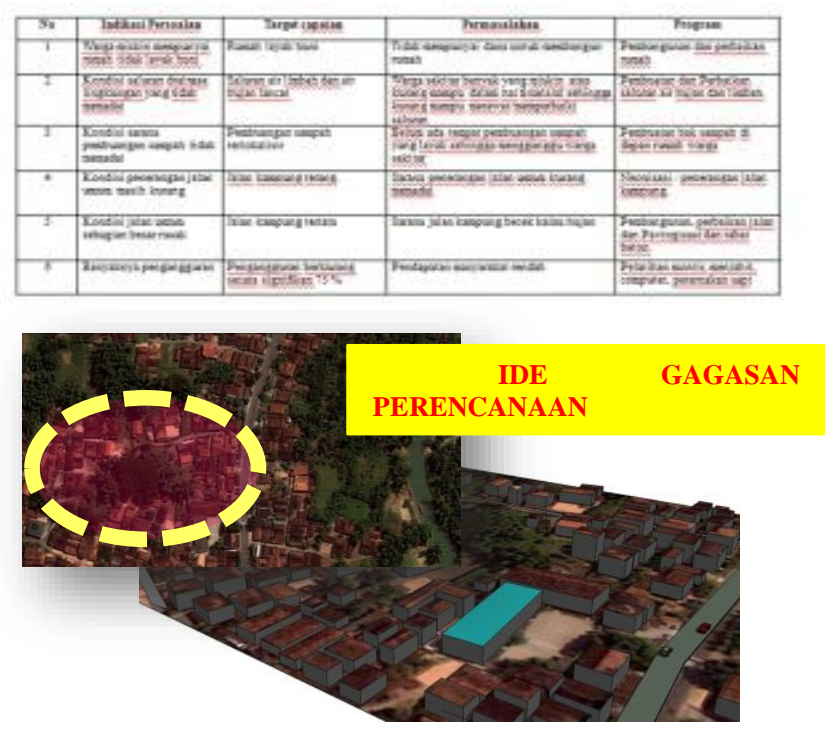

Gambar 6. Gagasan Fisik Penataan

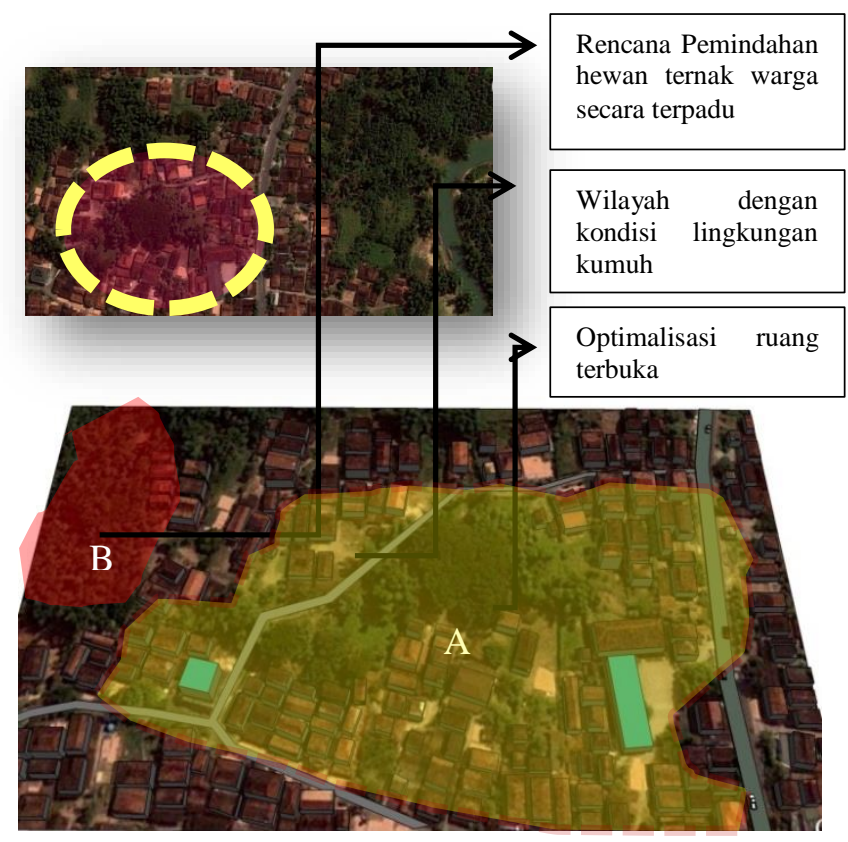

Gambar 7. Kondisi Bangunan dan Lingkungan 
Kondisi Bangunan dan Lingkungan

a. Tata bangunan

Permukiman belum tertata, belum ada orientasi masa bangunan

b. Fisik bangunan

Masih banyak hunian yang dalam kategori kurang layak huni.

c. Karakter Lingkungan

Lingkungan kumuh karena menjadi satunya antara hewan ternak dan permukiman.

d. Sarana \& Prasarana

Banyak permukiman yang tidak tidak mendapatkan akses jalan

Jaringan draenase lingkungan sangat minim Belum adanya jaringan SPAL

e. Sanitasi

Banyak permukiman yang belum memiliki MCK

Hunian di sekitar lahan kosong masih menempatkan hewan ternak menjadi satu dengan permukiman, di beberapa tempat hewan tetnak berada di dalam rumah yang tidak ada pembatas dengan pemiliknya. Sebagian rumah masih terbuat dari bilik dengan lantai tanah, kotoran hewan belum dikelola, kotoran masih mengunung di sisi sisi rumah. Daerah ini sangat rawan dengan berbagai penyakit karena kualitas lingkungan dan permukimanyang masih rendah, ditambah lagi belum semua hunian mempunya sanitasi yang memadahi, banyak yang masih buang hajat di sembarang tempat.
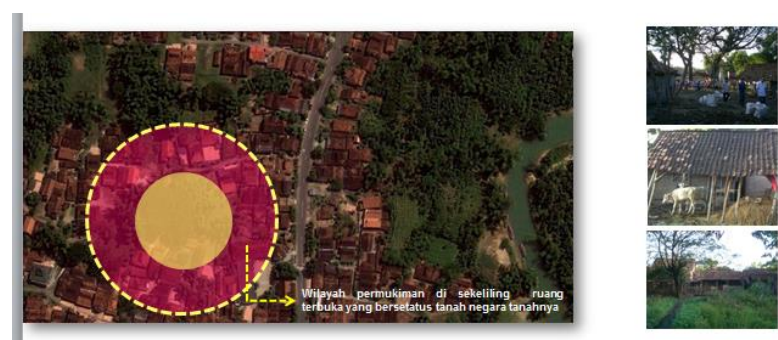

Gambar 8. Lahan Kosong dijadikan Kandang Sapi

Masyarakat yang terbelakang tentunya tidak dapat bangkit sendiri secara cepat tanpa adanya pendampingan pendampingan dari pemerintah maupun kelompok kelompok atupun individu yang perduli. Penyediaan ruang serta prasarana yang bisa menjadi media pembelajaran bersama akan pentingnya sebuah lingkungan yang baik sangat di perlukan. Penyediaan wadah bagi berbagai kegiatan positif yang ada di masyrakat sangat berpengaruh pada pemahaman masyarakat akan kondisi lingkungannya. Pemuda dapat menjadi motor pengerak untuk kemajuan suatu wilayah, selain itu kegiatan ibu ibu PKK sangat evektif dalam penyebaran informasi yang ada. Ruang publik yang mampu mewadahi berbagai kegiatan positif dalam rangka pemahaman akan pentingnya lingkungan permukiman yang baik/sehat. Ruang publik harapannya mampu menjadi embrio peningkatan dari segi sosial ,lingkungan maupun perekonomian.
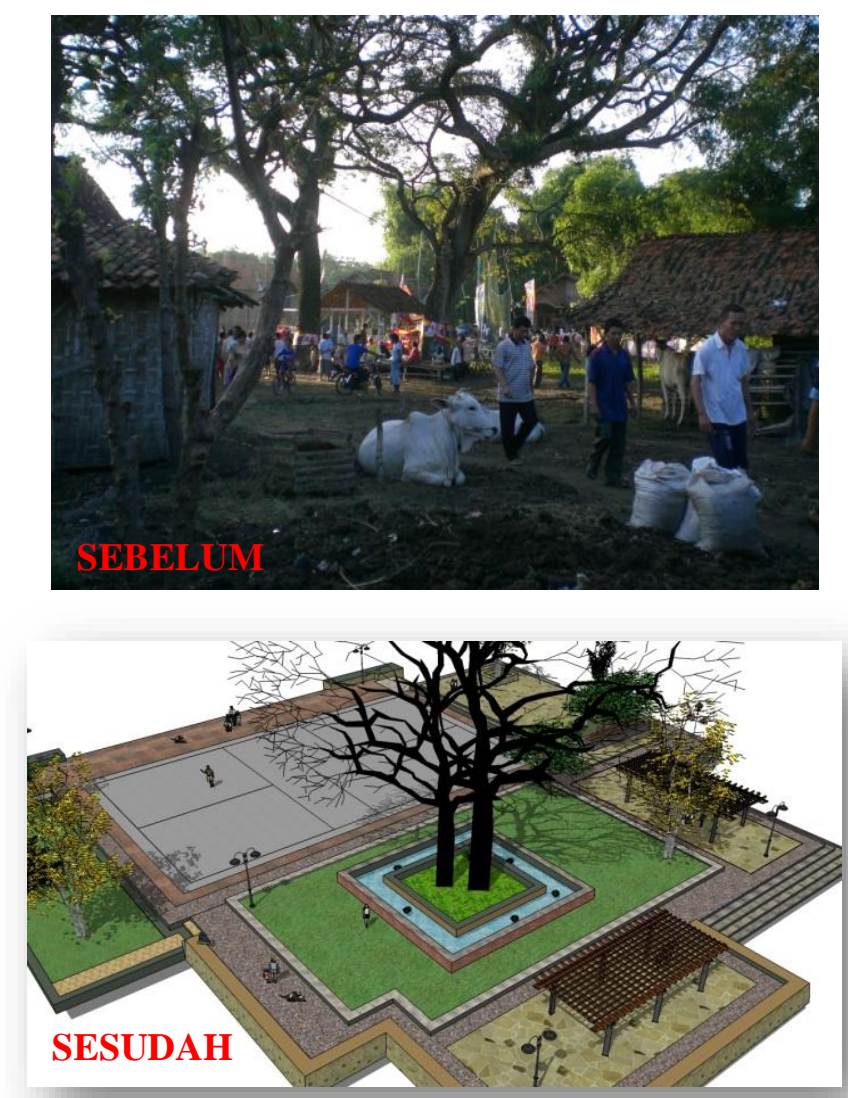

Gambar 9. Sebelum dan Sesudah Penataan

Selain penataan dan perencanaan permukiman, salah satu yang menjadi perhatian adalah optimalisasi ruang terbuka . Ruang publik yang mampu mewadahi berbagai aktifitas di masyarakat diharapkan menjadi embrio perbaikan di semua bidang,kesatuan perencanaan antara lingkungan permukiman dan prasarana pedukungnya sangatlah penting karena kesemuanya tidak dapat dipisahkan. Pengelompokan ternak serta pengelolaan bersama sangat memungkinkan karena ketersediaan lahan dan kemauan warganya, selain itu kotoran ternak sangat memungkinkan untuk dikelola menjadi biogas rumah tangga. 


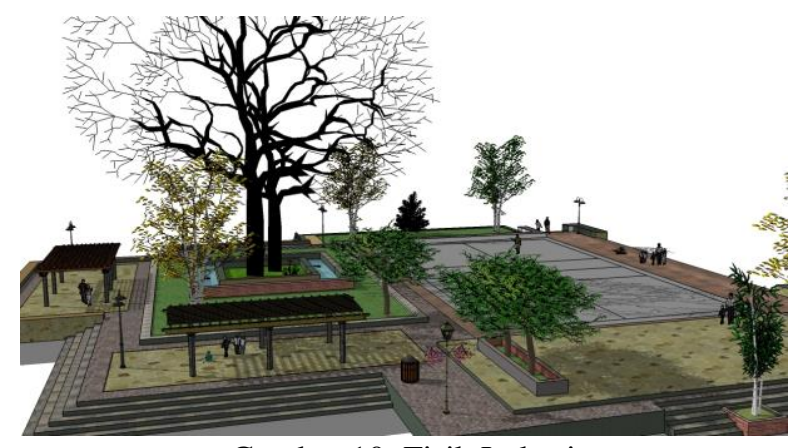

Gambar 10. Fisik Lokasi

Selain mampu merubah secara fisik dari lokasi yang kumuh menjadi tertata harapanya mampu berdampak luas terhadap peningkatan kualitas lingkungan sosial maupun ekonomi.

Berbagai kegitan yang bisa terwadahi dalam rencana ruang publik.

Kegiatan Kemasyarakatan:

- Peringatan peringatan (nasional/lokal)

- Even even Desa atu RW

- Acara acara adat

Orang tua:

- Penyuluhan penyuluhan

- Kegiatan Ibu ibu PKK ( posyandu dsb)

- Pelatihan

- Pengembangan ekonomi kerakyatan

Pemuda:

- Sarana kegiatan olah raga

- Tempat even even kepemudaan

- Pelatihan kerja

Anak anak:

- Tempat Olah Raga

- Tempat bermain

Kondisi saat ini lokasi sangat teduh dan nyaman karena keberadaan dua pohon munggur besar

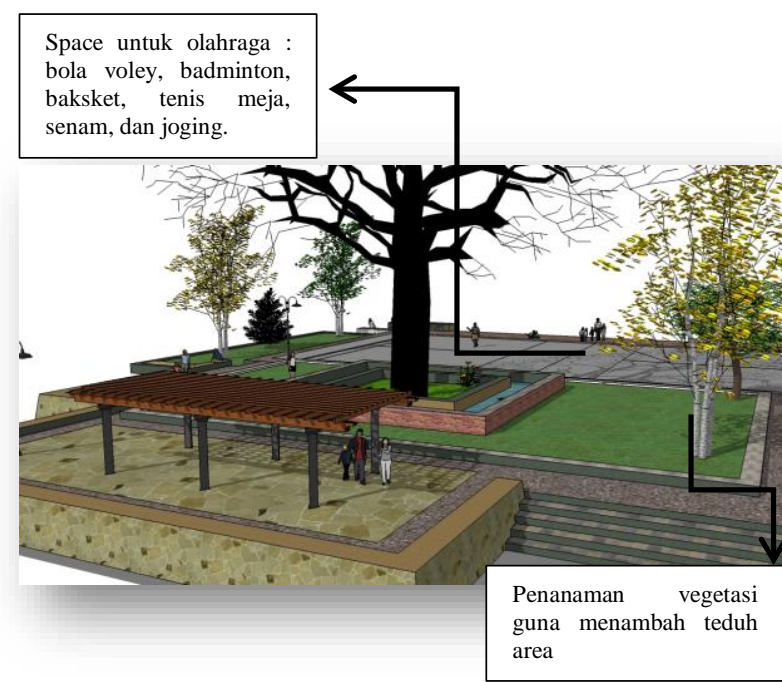

Gambar 11. Ruang terbuka
Perencanaan juga menyertakan sarana penunjang penataan ruang terbuka seperti; ketersediaan lampu lampu taman, tempat sampah, dan desain peninggian dan penurunan elevasi desain daat sebagai tempayt duduk.

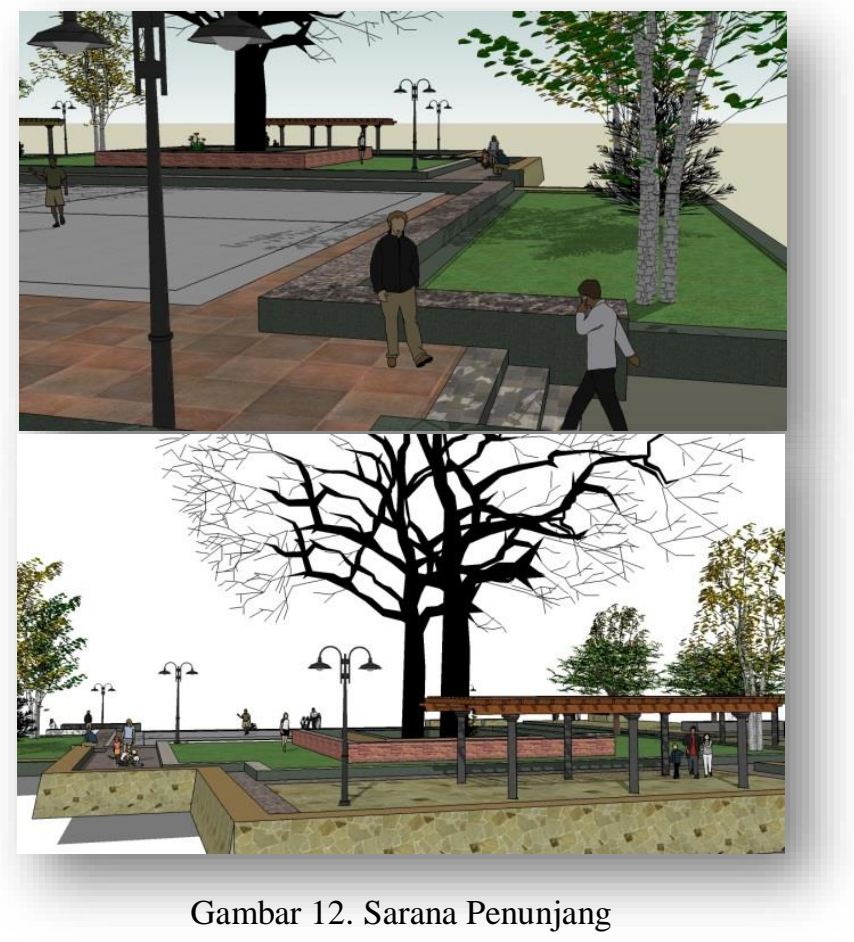

Disamping ada peninggian dasar site untuk mengatasi genangan di musim hujan, saluran draenase juga terintegrasi dalam desain

\section{PENUTUP \\ Simpulan}

Berdasarkan hasil penelusuran dan kajian awal terhadap kondisi eksisting Desa Waru dapat disimpulkan sebagai desa yang memiliki potensi lokal yang belum dimaksimalkan baik itu sumber daya alam maupun sumber daya manusianya. Melihat potensi tersebut, mencoba mengerucutkan arahan pengembangan Desa Waru pada masa yang akan datang dalam bentuk Desa Mandiri Energi. Desa Waru nantinya mampu mengembangkan sumber daya alam dan sumber daya manusianya secara maksimal dan juga mampu meningkatkan perekonomian desa yang juga berdampak kepada peningkatan perekonomian masyarakat. Untuk itu diperlukan arahan dan strategi dalam mengembangkan Desa Waru menjadi Desa Mandiri Energi tersebut sebagai berikut:

Guna meningkatkan kualitas lingkungan dan perekonomian Desa Waru diperlukan arahan 
yang tegas yang nantinya menjadi panduan dalam upaya mengembangkan sumber daya alam dan sumber daya manusia, meliputi:

Memaksimalkan sumber energi yang ada untuk dipakai dan dikembangkan.

Melakukan kajian terhadap sumber energi terbaharukan.

Melakukan koordinasi dengan pihak terkait pengembangan sumber energi terbaharukan dan penerapannya.

Untuk mencapai upaya peningkatan kualitas lingkungan dan perekonomian diperlukan strategi yang nantinya dijadikan acuan dalam melakukan kegiatan pengambangan dan pengelolaan energi terbaharukan melalui:

Memberdayakan masyarakat desa dengan membuat kelompok sadar energi.

1. Melakukan penyuluhan dan pelatihan pengembangan energi terbaharukan.

2. Melakukan sosialisasi penghematan energi dan pola hidup yang sehat.

3. Melakukan koordinasi dengan Pemerintah Daerah dan lembaga-lembaga pengembangan sumber energi terbaharukan.

4. Melakukan pembinaan dan pengelolaan komoditas unggulan terhadap kelompok tani

Saran dan peternak dalam mengembangkan usahanya

Saran dimaksud untuk penelitian selanjutnya.

\section{DAFTAR PUSTAKA}

Kamus Tata Ruang. 1998. Direktorat Jendral Cipta Karya, Departemen Pekerjaan Umum bekerjasama dengan Ikatan Ahli Perencanaan Indonesia.

Komaruddin. 1996. Menelusuri Pembangunan Perumahan dan Permukiman. Jakarta : Yayasan REI.

Direktorat Pengembangan Permukiman, Direktorat Jenderal Cipta Karya dan Departemen Pekerjaan Umum. 2006. Identifikasi Kawasan Permukiman Kumuh Daerah Penyangga Kota Metropolitan.

Sobirin. 2001. Distribusi Pemukiman dan Prasarana Kota: Studi Kasus Dinamika Pembangunan Kota di Indonesia. Universitas Indonesia, Jakarta.

Sugiyono. 2013. Metode Penelitian Pendidikan : Pendekatan Kuantitatif, Kualitatif, dan R \& D. Bandung : Alfabeta.

Undang-undang Nomor 1 Tahun 2011 tentang Perumahan dan Kawan Pemukiman Undang-undang Nomor 4 Tahun 1992 Tentang Perumahan 